\title{
CONCEPT AND REALIZATION OF BACKPACK-TYPE SYSTEM FOR MULTICHANNEL ELECTROPHYSIOLOGY IN FREELY BEHAVING RODENTS
}

\author{
Olga Chaikovska ${ }^{1}$, Olexandr Ponomarenko ${ }^{1}$, Olexandr Dovgan ${ }^{1}$, Igor Rokunets ${ }^{1}$, Sergii Pavlov ${ }^{2}$, \\ Olena Kryvoviaz ${ }^{1}$, Oleg Vlasenko ${ }^{1}$ \\ ${ }^{1}$ National Pirogov Memorial Medical University, Vinnytsia, Ukraine; ${ }^{2}$ Vinnytsia National Technical University, Vinnytsia, Ukraine
}

\begin{abstract}
Technologies for multichannel electrophysiology are experiencing astounding growth. Numbers of channels reach thousands of recording sites, systems are often combined with electrostimulations and optic stimulations. However, the task of design the cheap, flexible system for freely behaving animals without tethered cable are not solved completely. We propose the system for multichannel electrophysiology for both rats and mice. The system allows to record unit activity and local field potential (LFP) up to 32 channels with different types of electrodes. The system was constructed using Intan technologies RHD 2132 chip. Data acquisition and recordings take place on the DAQ-card, which is placed as a back-pack on the animal. The signal is amplified with amplifier cascade and digitalized with 16-bit ADC. Instrumental filters allow to filter the signal in 0.1-20000 Hz bandwidth. The system is powered from the mini-battery with capacity $340 \mathrm{~mA} / \mathrm{hr}$. The system was validated with generated signals, in anaesthetized rat and showed a high quality of recordings.
\end{abstract}

Keywords: multichannel electrophysiology, freely behaving rodents, unit activity, local field potential

\section{KONCEPCJA I REALIZACJA SYSTEMU PLECAKOWEGO DLA WIELOKANALOWEJ ELEKTROFIZJOLOGII U SWOBODNIE ZACHOWUJĄCYCH SIE GRYZONI}

\begin{abstract}
Streszczenie. Technologie elektrofizjologii wielokanałowej odnotowuja zdumiewający wzrost. Liczba kanałów dociera do tysięcy miejsc rejestracji, systemy czesto łaczone sa z elektrostymulacjami i stymulacjami optycznymi. Jednak zadanie zaprojektowania taniego, elastyczne go systemu pozwalajacego na swobodne zachowania zwierzat bez przywiazanego kabla nie zostało całkowicie rozwiazane. Zaproponowano system wielokanałowej elektrofizjologii zarówno dla szczurów, jak i myszy. System pozwala rejestrować aktywność jednostki i potencjat pola lokalnego (LFP) do 32 kanałów z różnymi rodzajami elektrod. System zostat zbudowany przy użyciu technologii Intan RHD 2132. Akwizycja danych i nagrania odbywaja się na karcie DAQ, która zostata umieszczona w plecaku zwierzęcia. Sygnat jest wzmacniany kaskada wzmacniaczy i digitalizowany za pomoca 16-bitowego przetwornika ADC. Filtry pozwalaja filtrować sygnat $w$ paśmie 0,1-20000 Hz. Zasilany jest z mini-baterii o wydajności $340 \mathrm{~mA} / \mathrm{godz}$. System został zwalidowany generowanymi sygnałami u znieczulonego szczura i wykazał wysoka jakość nagrań.
\end{abstract}

Słowa kluczowe: elektrofizjologia wielokanałowa, gryzonie swobodnie zachowujące się, aktywność jednostkowa, potencjał pola lokalnego

\section{Introduction}

Nervous system works and codes information in the form of various electrical events: series of individual spikes, local potentials and up to complex brain oscillations. Today's scientific world has many different techniques for brain imaging and investigation, however the measuring of electrical activity in different scales is an essential part to understand the principles of the brain functioning. Also nowadays this field of research undergoes rapid increasing in numbers of channels for recording systems and fast evolution in hardware and software. Systems that enable recordings in freely behaving animals are typically complex and do not have enough flexibility. Even rapid growing low-cost open-source systems do not fully correspond to the needs for experiments, which require animal to be completely freely behaving. Most of such systems work with animals with implanted electrode array and head stages connected with data acquisition modules by cables and tethers. We present here the concept of a low-cost backpack system for multichannel recordings in freely behaving animals.

\section{Aim and task of the research}

In the current paper, we discussed the design of flexible system for extracellular recordings in rodents from freely accessible parts.

\section{Analysis of alternative open-source systems}

Fast evolution of microelectronics and increased requirements for flexibility of systems for electrophysiology triggered a series of projects for low-cost open source recording systems in rodents, monkey and humans $[10,13,15,17,18,25,29]$. The first opensource and low-cost systems for multichannel physiology include A/D system in 1994 created in Bruce McNaughton's lab, which was redesigned as ArtE later (https://github.com/imalsogreg/arte- ephys). The next was MEA Bench in 2000 created by Daniel Wagenaar, Tom Demarse, and Steve Potter [25]. Neuro Righter system was developed in 2000th by John Rolston, Riley ZellerTownson, and Jon Newman [10, 13, 15]. The cost of Neuro Righter had fallen from $60000 \$$ to $10000 \$$ compared with the MEA Bench [17] due to recent progress of electronic components.

The next boom started after production of amplifier chips RHD, RHA and RHS series by Intan Technologies, when Jacob Voigts and Josh Siegle found Open Ephys initiative, which included acquisition board and dynamically evolved software for close-looped experiments [18, 29]. It consists of hardware block using FPGA-based acquisition card for recordings and software package for real-time data visualization and analysis. It allows recordings from 128-512 channels simultaneously with real-time spike sorting and detection. However, this system requires commercial Intan technologies head stage. The head stage should be installed on the animal skull and animal is tethered during recordings [3, 18, 28]. Open Ephys system becomes the most wide-used closed-loop system for multichannel electrophysiology in different laboratories all over the world.

Also a lot of small projects were developed in different laboratories including both recording and stimulation options $[2,4,9,16,27]$.

The last outbreak in the field of multichannel electrophysiology was in 2017, made by collaboration of Howard Hughes Medical Institute, Welcome Trust, Gatsby Charitable Foundation and Allen Institute for Brain Science. They developed shank probe with amplifiers cascade and ADC located directly on the probe and capable to record from more than 400 sites simultaneously [8, 11, 21, 22]. Neuropixel probe is not completely open-source project, however it can work with different hardware, it is flexible and has the lowest price per channel. These characteristics make Neuropixel the cheapest alternative compared even with open-source platforms. However, animals are tethered in their configuration also [1,6]. 
Cost of the recording systems has dropped by near two orders from the A/D system to the lowest level for Neuropixel today (Fig. 1) $[10,13,15,17,21,22,25]$. Price per channel for our system is about 22 USD.

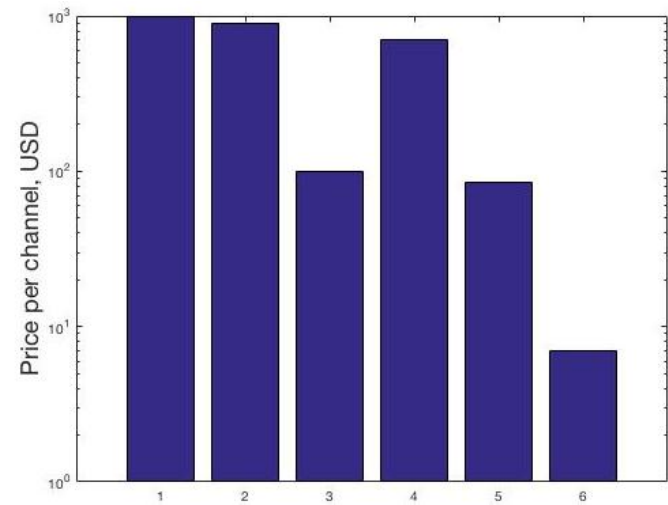

Fig. 1. Cost per channels for different recording systems has decreased by nearly two orders for last decades (1-A/D (1994), 2 - MEABench (2000), 3 - NeuroWrighter (2008), 4-ArtE (2011), OpenEphys 5-(2012), 6-NeuroPixel (2017))

As was mentioned above, development of low-cost, compact and flexible system from freely accessible parts allowing recordings from untethered animals is still actual. Realizations of such recordings in completely freely behaving animals are possible in two general concepts. The first one uses wireless signal transmission gathered from the implanted electrode array mounted on the skull of animal or on the animal itself as a backpack. Then with a receiver, analogous or already digitalized signal is transmitted recorded on PC [5]. In the second concept all cycle of data collection can be realized on the animal and data can be recorded on the memory card [20,24]. The main problems of such systems are high power consumption, limitation for numbers of channels and operational time. The second concept is autonomous system, which can give to researchers an option to make recordings in untethered animals.

The aim of the study: Development and validation of low-cost system for multichannel electrophysiological recordings in anaesthetized and freely behaving animals in the framework of second concept.

\section{Material and methods}

The system was developed for unit activity and LFP recordings in anaesthetized and freely behaving animals. DAQmodule powered with mini-battery was designed to be mounted as a back-pack in animal and should be connected with electrode array by use of a flat flex cable (Fig. 2).

DAQ card for multichannel electrophysiology based on core Intan RHD2132 chip. This chip includes fully integrated lownoise amplifier array, adjustable analogue filters and 16-bits ADC ADC operation is 1.05 MSamples per second and supports sampling 32 amplifier channels at $30 \mathrm{kSamples} / \mathrm{s}$ sampling rate for each channel (Fig. 3). Also the chip includes optional on-chip DSP high-pass filters for amplifier offset removal and auxiliary ADC inputs for interfacing additional sensors [29]. Parameters of the system are shown in Table 1.

Microcontroller STM32L12KB is operated with the core chip through SPI or low-voltage digital signal interface (LVDS). Data transfer occurs using additional FRAM memory to compensate small buffer size allocated in the microcontroller memory. Data are recorded in the microSD card as binary file and can be processed offline after finish the recordings (Fig. 4). Filter's parameters, list of active channels and sampling rate can be programmed through custom-written software $(\mathrm{C}++)$ before start of experiment. Recordings can be initiated and finished with pressing of button on the board. LED indicates start and finish of recordings, charge level of battery and presence of microSD card by blinking in specific manner for each case.

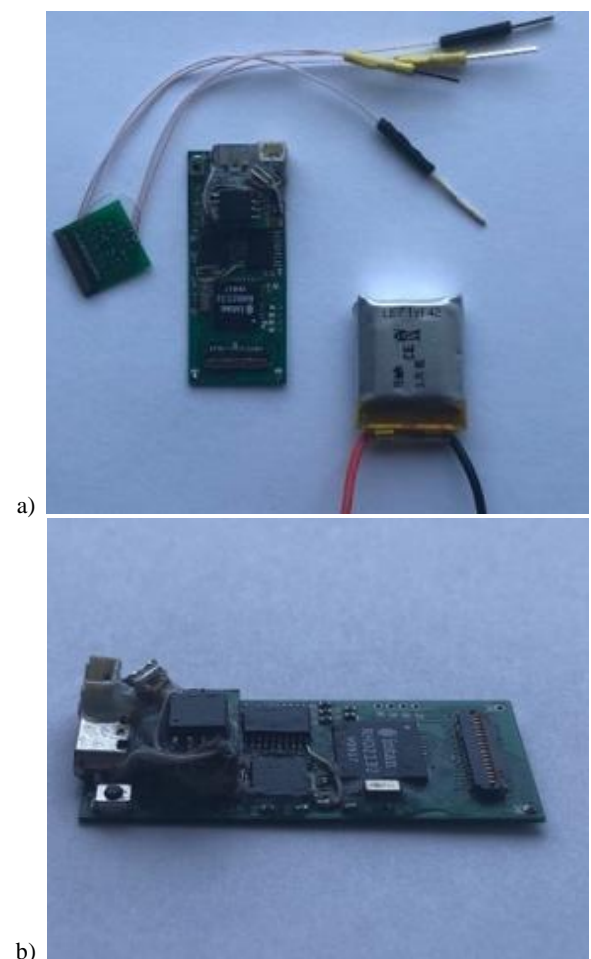

Fig. 2. General (top and side) view of the DAQ card, battery and connectors for signal simulation

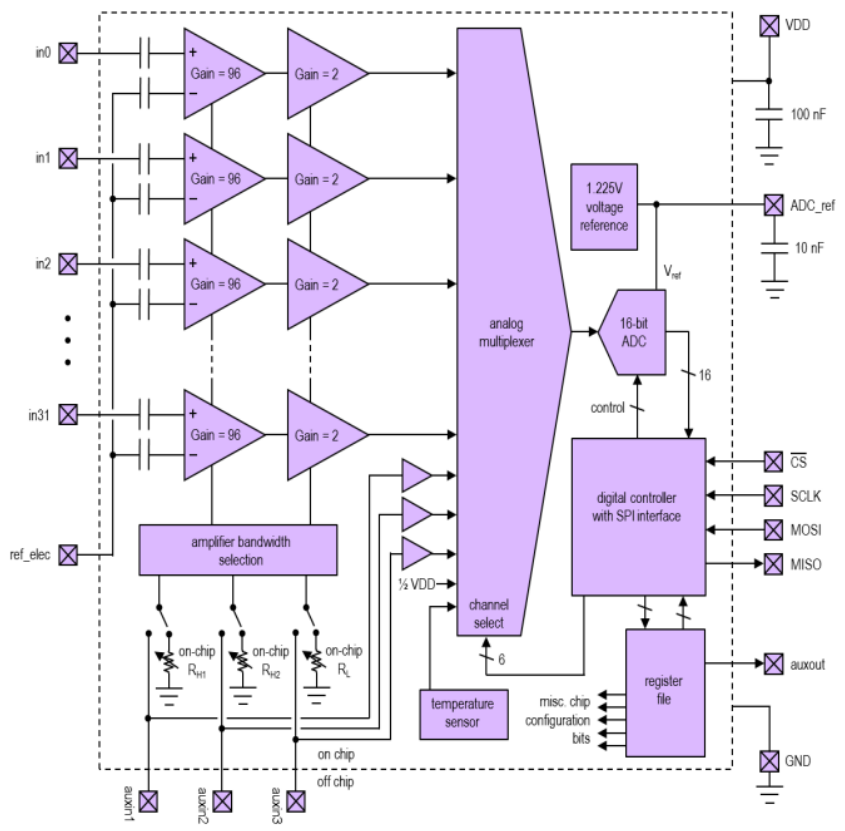

Fig. 3. Simplified core chip diagram from Intan RHD series datasheet [29]

Table 1. Properties of the data acquisition system

\begin{tabular}{|c|c|}
\hline Parameter & Value \\
\hline Dimensions & $17 \times 41 \mathrm{~mm}$ \\
\hline Weight without battery & $2.95 \mathrm{~g}$ \\
\hline Battery weight & $5.05 \mathrm{~g}$ \\
\hline No. of channels (programmable) & up to 32 \\
\hline Gain & $192 \mathrm{~V} / \mathrm{V}$ \\
\hline Filers range (fLC/fUC) programmable & $0.5-500 \mathrm{~Hz} / 100-20000 \mathrm{~Hz}$ \\
\hline Input referred noise & $2.4 \mu \mathrm{Vrms}$ \\
\hline
\end{tabular}






Fig. 4. Block-scheme of data acquisition card: signal from implanted electrode array, connected to DAQ module with FPC cable, collected with Intan RHD2132 core chip (signal is amplified, filtered and digitalized). Core chip is operated by microcontroller (MCU STM32L432KB). MCU using FRAM records data on the microSD card. System is powered with Li-polymer battery (Li-Pol). LVDS Driver - driver of low-voltage differential signaling, S1-switch, LDI-signaling LED, Q1-phototransistor, LDO - low drop out regulator

Custom software was written for our DAQ-card. Data acquisition was organized in the following flow chart:

- Intan RHD2132 chip is connected to $\mu \mathrm{C}$ by SPI3 $-\mu \mathrm{C}$ uses SPI3 to connect to $\mu \mathrm{SD}$-card;

- $\quad 32 \mathrm{kB}$ buffer of command array is transferred to the Intan in cyclic mode through SPI using DMA TX channel;

- $32 \mathrm{kB}$ array with data is received in cyclic mode simultaneously using DMA RX channel;

- Recordings on the $\mu \mathrm{SD}$-card is made by $16 \mathrm{kB}$ blocks;

- Writing speed should be more than capture of data;

- $\mu \mathrm{SD}$-card shows $250 \mathrm{~ms}$ time gaps during recordings, that is why data is collected in the intermediary buffer in the external FRAM memory by $16 \mathrm{kB}$ blocks.

To test the accuracy of data acquisition we conducted several bench tests. The first stages of system validation were performed with generated signals. The signals were sent and detected with known signals on the different channels of the system. Tests were carried out in different frequency range, sampling rates and connection of electrode array to DAQ card to check the functionality and accuracy of recordings.
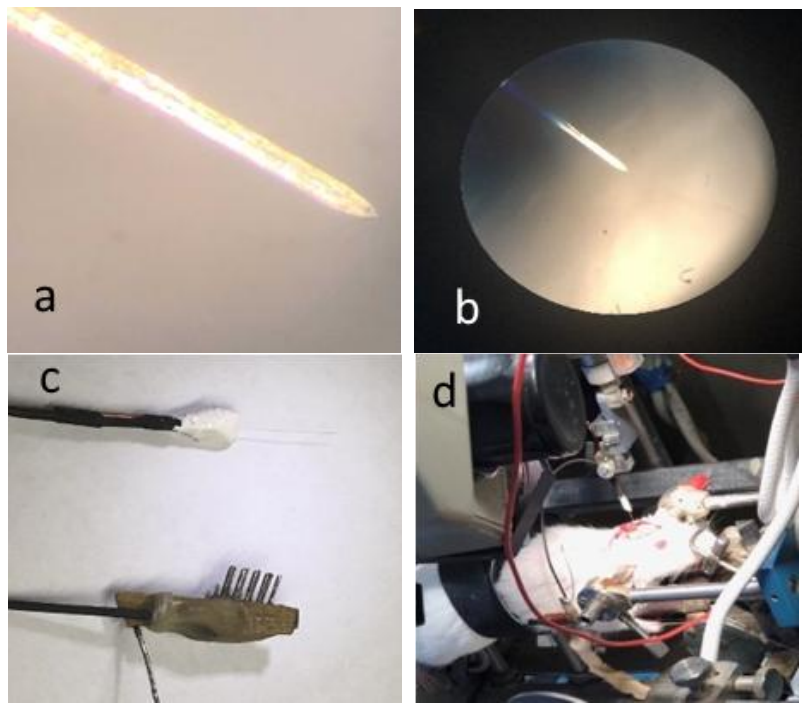

Fig. 5. $(a, b)$ - tip of the 8-channel electrode array; $(c)$ - 8-channel electrode array with connector for signal visualization on oscilloscopes, $(d)$ - animal with implanted electrodes during recordings
At the next stage, the system was validated on the anaesthetized rats. 8-channel microware array was implanted in the hippocampal area of adult Wistar rat. Experiment was carried out in accordance with the National general principles for experiments on animals. The rat was anaesthetized with ketamine $(100 \mathrm{mg} / \mathrm{kg})$-xylazine $(10 \mathrm{mg} / \mathrm{kg})$ as intraperitoneal injection and was given subcutaneous injection of lidocaine to minimize pain [19]. Craniotomy was made in the projection of right hippocampus $(4.2 \mathrm{~mm}-\mathrm{P}, 3.6 \mathrm{~mm}-\mathrm{L})$. Dura was pricked and microelectrode array was implanted. Array consisted of 8 tungsten wire with $\mathrm{d}=12 \mu \mathrm{m} /$ each electrode (Fig. 5).

The electrode array had integrated reference coil and ground wire, which were placed around drilled hole under the skull. Using custom made micro-manipulator, the electrode array was moved into the targeted brain area with the $5 \mu \mathrm{m}$ step, until stable neural signal was recorded. Verification of a single unit activity was proved with wireless 8-channel system for extracellular electrophysiology $[12,14,23]$ with simultaneous visualization of signal on oscilloscopes $[6,26]$.

\section{Results and discussion}

Fabrication, assembling and programming of the system had taken about 8 months. All parts of DAQ-card are freely accessible. Validation was performed on the generated signals, which were sent directly to the DAQ-card inputs through custom made PCBboard with electrodes and connector on the first stage (Fig. 6a) or through 8-channels microelectrode array through saline on the second stage (Fig. 6b). Tests showed high quality of signal and no cross-talk between the channels (Fig. 6a).

On the second stage the signals with different frequency were sent to DAQ-module from 8-channel microelectrode array through saline. Fourier transform confirmed data acquisition accuracy (Fig. 7).

At the next stage, the neural signal was recorded from hippocampal area of anaesthetized rat. The signal processing and spike detection were done offline. The signal was filtered between $244 \mathrm{~Hz}$ and $6 \mathrm{kHz}$ with $4^{\text {th }}$ order Butterworth band pass filter and spikes were extracted (Fig. 8).

In the current version, our system does not include several necessary options, such as synchronization with external devices, visualization of data, spike detection and sorting modules. We plan to expand functionality in the next modifications. 

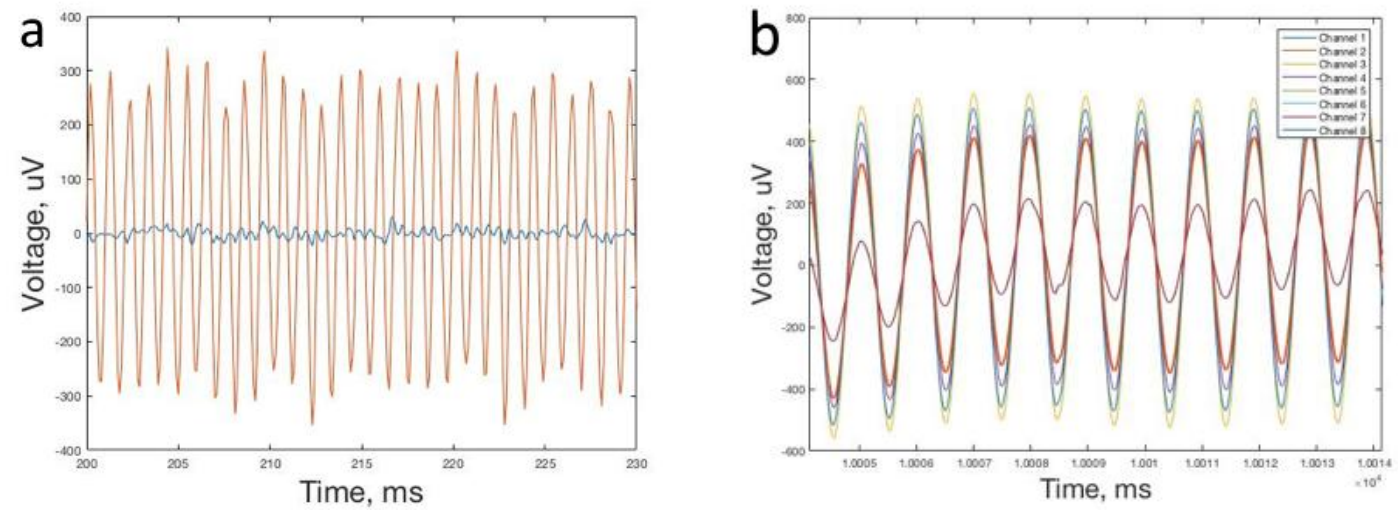

Fig. 6. a) simulated signal was sent to DAO-card directly. Data from channel 1 and channel 4 are presented, signal parameters: amplitude - 300 $\mu \mathrm{V}$, frequency - $1000 \mathrm{~Hz}$ on channel 1 (red curve), channel 4 was grounded (blue curve), b) simulated signal was sent to DAQ-module directly. 8 channels are shown signal parameters amplitude $-\sim 500 \mu \mathrm{V}$, frequency $-1000 \mathrm{~Hz}$
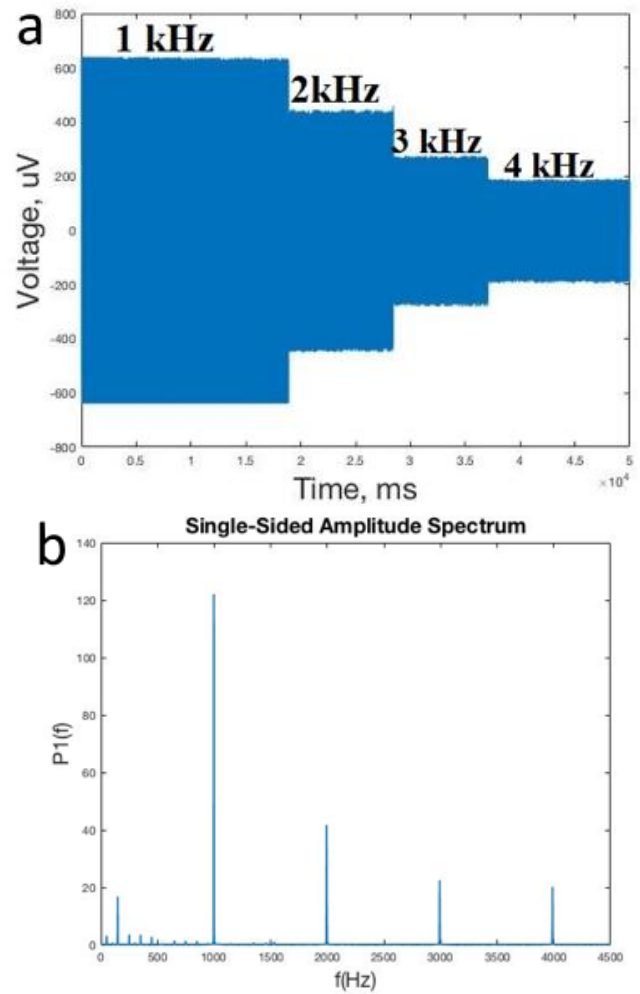

Fig. 7. Generated sine wave recorded with $D A Q$-card, data from channel 1 are presented. Signal parameters: (a) voltage - 300 $\mathrm{V}$, frequency $1 \mathrm{kHz}, 2 \mathrm{kHz}, 3 \mathrm{kHz}$ $4 \mathrm{kHz}(b)$ Fourrier transform of recorded signal showed peaks on the testing frequencies

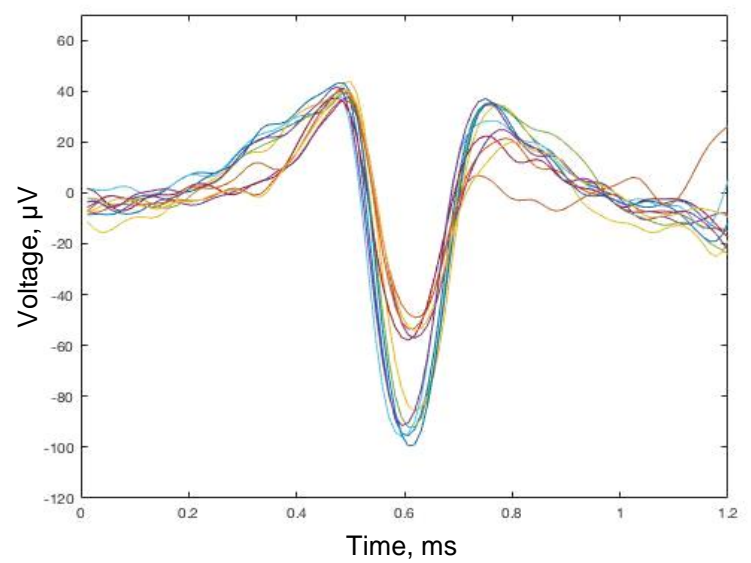

Fig. 8. Superposition of detected and separated spikes after signal processing

\section{Conclusions}

Designed open source low-cost system for multichannel electrophysiology was built on widely used parts and can record simulated and neural signals with high accuracy. It can be used in different modes for particular experimental requirements. It has several limitations - lack of memory for stable recordings at high sampling rates, does not have option to be precisely synchronized with other devices, absence of real-time data visualization and spike detection and sorting functions. Further optimizations of the system are underway and can overcome most of these limitations to extend the modes of data acquisition and increase experimental flexibility.

\section{References}

[1] Al_Omari A. K., Saied H. F. I., Avrunin O. G.: Analysis of Changes of the Hydraulic Diameter and Determination of the Air Flow Modes in the Nasal Cavity. Image Processing and Communications Challenges 3. Springer, Berlin, Heidelberg 2011, [DOI: 10.1007/978-3-642-23154-4_34].

[2] Alam M., Chen X., Fernandez E.: A low-cost multichannel wireless neural stimulation system for freely roaming animals. Journal of neural engineering 10(6), 2013, 066010.

[3] Bennett C. et al.: Higher-order thalamic circuits channel parallel streams of visual information in mice. Neuron 102(2), 2019, 477-492.

[4] Erickson J. C. et al.: Intsy: a low-cost, open-source, wireless multi-channel bioamplifier system. Physiological measurement 39(3), 2018, 035008.

[5] Fan D., Rich D., Holtzman T., Ruther P., Dalley J. W., Lopez A., et al.: A wireless multi-channel recording system for freely behaving mice and rats. PLoS ONE 6(7), 2011, e22033, [DOI: 10.1371/journal.pone.0022033].

[6] Fyrmpas G. et al.: The value of bilateral simultaneous nasal spirometry in the assessment of patients undergoing septoplasty. Rhinology 49(3), 2011, 297-303.

[7] Ghomashchi A. et al.: A low-cost, open-source, wireless electrophysiolog system. 36th Annual International Conference of the IEEE Engineering in Medicine and Biology Society, 2014.

[8] Juavinett A. L., Bekheet G., Churchland A. K.: Chronically implanted Neuropixels probes enable high-yield recordings in freely moving mice. eLife 8 , 2019, e47188.

[9] Kinney J. P. et al.: A direct-to-drive neural data acquisition system. Frontiers in neural circuits 9, 2015, 46, [DOI: 10.3389/fncir.2015.00046].

[10] Laxpati N. G. et al.: Real-time in vivo optogenetic neuromodulation and multielectrode electrophysiologic recording with NeuroRighter. Frontiers in neuroengineering 7, 2014, 40.

[11] Liang B., Ye X.: Towards high-density recording of brain-wide neural activity. Science China Materials 61, 2018, 432-434, [DOI: 10.1007/s40843017-9175-3].

[12] Moroz V. M. et al.: Coupled Spike Activity in Micropopulations of Motor Cortex Neurons in Rats. Neurophysiology 42(2), 2010, 110-117.

[13] Newman J. P. et al.: Closed-loop, multichannel experimentation using the opensource NeuroRighter electrophysiology platform. Frontiers in neural circuits 6 , 2013, 98 .

[14] Nosova Ya. V., Faruk K. I., Avrunin O. G.: A tool for researching respiratory and olfaction disorders. Telecommunications and Radio Engineering 77(15), 2018, 1389-1395.

[15] Rolston J. D., Gross R. E., Potter S. M.: NeuroRighter: closed-loop multielectrode stimulation and recording for freely moving animals and cell cultures. Annual International Conference of the IEEE Engineering in Medicine and Biology Society, 2009.

[16] Rotermund D. et al.: Open hardware: Towards a fully-wireless sub-cranial neuro-implant for measuring electrocorticography signals. BioRxiv 036855, 2017. 
[17] Siegle J. H. et al.: Neural ensemble communities: open-source approaches to hardware for large-scale electrophysiology. Current opinion in neurobiology 32 , 2015, 53-59.

[18] Siegle J. H. et al.: Open Ephys: an open-source, plugin-based platform for multichannel electrophysiology. Journal of neural engineering 14(4), 2017, 045003.

[19] Sikes R. S., Gannon W. L. Guidelines of the American Society of Mammalogists for the use of wild mammals in research. Journal of Mammalogy 92(1), 2011, 235-253.

[20] Spivey R. J., Bishop Ch. M.: An implantable instrument for studying the longterm flight biology of migratory birds. Review of Scientific Instruments 85(1), 2014, 014301.

[21] Steinmetz N. A. et al.: Challenges and opportunities for large-scale electrophysiology with Neuropixels probes. Current opinion in neurobiology 50, 2018, 92-100.

[22] Steinmetz N. et al.: Dataset: simultaneous recording with two Neuropixels Phase 3 electrode arrays. CortexLab at UCL, 2016.

[23] Vlasenko O. et al.: Multichannel system for recording myocardial electrical activity. Information Technology in Medical Diagnostics II: Proceedings

\begin{abstract}
M.Sc. Olga Chaikovska
e-mail: chaikovska.olga@ vnmu.edu.ua

Ph.D. student at the Department of Human Physiology, Vinnytsia.

The field of scientific interest is dopaminergic system pathology, changing inneural dynamics and behavior during neurodegenerative diseases, electrophysiological markers (early stages) for neurodegenerative diseases.
\end{abstract}

\section{ORCID ID: 0000-0002-6489-6040}

\section{Eng. Oleksandr Ponomarenko}

e-mail: alux.ponomarenko@gmail.com

Engineer at the Department of Human Physiology.

Scientific interests: hardware development of data acquisition system for biopotentials recordings in small animals.

ORCID ID: 0000-0002-3058-7637

\section{Ph.D. Oleksandr Dovgan
e-mail: alexander.d1980@gmail.com}

Docent at the Department of Human Physiology. Scientific interests is focused on the organization of motor programs in different cortical area and subcortical structures, investigation of neural processes during motor learning, changes in neuronal activity in hypothalamus and amygdala during prolonged starvation and after operant movements learning.

\section{ORCID ID: 0000-0002-8740-0650}

\section{Ph.D. Ihor Rokunets}

e-mail: rokunets@vnmu.edu.ua

Docent at the Department of Human Physiology. Scientific interests: electrical activity of neurons on the group level in the motor cortex and hippocampus; development of neurophysiological equipment (electrophysiology), polycardiography (phonoCG, ECG, ballistocardiography) on the open heart and in freely behaving animals, techniques for dynamic assessment of human pose and algorithm for data analysis.

ORCID ID: 0000-0002-8255-6007 of the International Scientific Internet Conference "Computer Graphics and Image Processing" and the XLVIIIth International Scientific and Practical Conference "Application of Lasers in Medicine and Biology". CRC Press, 2019.

[24] Vyssotski A. L. et al.: Miniature neurologgers for flying pigeons: multichannel EEG and action and field potentials in combination with GPS recording. Journal of neurophysiology 95(2), 2006, 1263-1273.

[25] Wagenaar D., DeMarse T. B., Potter S. M.: MeaBench: A toolset for multielectrode data acquisition and on-line analysis. Conference Proceedings. 2nd International IEEE EMBS Conference on Neural Engineering, 2005.

[26] Wójcik W., Pavlov S., Kalimoldayev M.: Information Technology in Medical Diagnostics II. CRC Press, London 2019, [DOI: 10.1201/9780429057618].

[27] Woods V. et al.: A low-cost, 61-channel $\mu \mathrm{ECoG}$ array for use in rodents. 7th International IEEE/EMBS Conference on Neural Engineering (NER), 2015.

[28] Yüzgeç Ö. et al.: Pupil size coupling to cortical states protects the stability of deep sleep via parasympathetic modulation. Current Biology 28(3), 2018, 392-400.

[29] RHD2000 Series Digital Electrophysiology Interface Chips RHD2116, RHD2132. Intan Technologies, LLC. http://intantech.com/files/Intan_RHD2000_series_datasheet.pdf

\section{Prof. Sergii Pavlov \\ e-mail:psv@vntu.edu.ua}

Doctor of Technical Sciences, Professor, Academician of the International Academy of Applied Radioelectronic. Vice-rector of for Scientific Work of Vinnytsia National Technical University, professor of biomedical Engineering

Scientific direction - biomedical information optoelectronic and laser technologies for diagnostics and physiotherapy influence. Deals with issues of improving the distribution of optical radiation theory in biological objects, particularly through the use of electro-optical systems, and the development of intelligent biomedical optoelectronic diagnostic systems and standardized methods for reliably determining the main hemodynamic cardiovascular system of comprehensive into account scattering effects.

ORCID ID: 0000-0002-0051-5560

\section{D.Sc. Olena Kryvoviaz}

e-mail: 16124sk@gmai.com

Doctor of Sciences, docent

The head of Department of Pharmacy of National

Pirogov Memorial University of Vinnytsia.

Scientific direction - pharmacy technology.

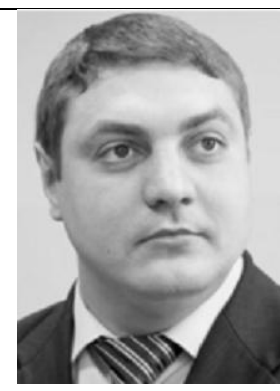

ORCID ID: 0000-0001-5441-1903

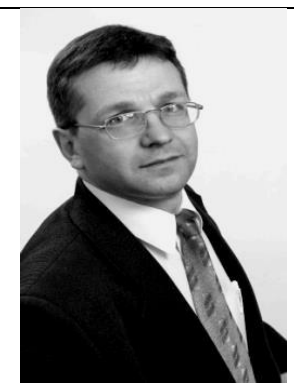

\section{Prof. Oleg Vlasenko}

e-mail: vlasenko@vnmu.edu.ua

Doctor of Medical Sciences, Professor. Vice-rector of for Scientific Work of National Pirogov Memorial University of Vinnytsia, professor at the Department of Human Physiology.

Scientific direction - neural circuits that are responsible for voluntary control of movements, interaction between autonomic and somatic divisions of CNS during operant movements, detection of stress by dynamical position of body center mass and physiological parameters.

ORCID ID: 0000-0001-8759-630X

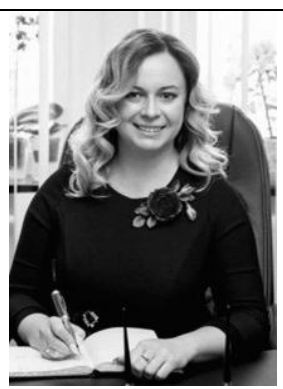

otrzymano/received: 01.11.2019

przyjęto do druku/accepted: 06.12.2019 